\title{
A Record of Lateglacial and Early Holocene Environmental and Ecological Change from Southwestern Connecticut, USA
}

\section{Citation}

Oswald, W. Wyatt, David Russell Foster, Elaine D. Doughty, and Edward Kerr Faison. 2009. A record of Lateglacial and early Holocene environmental and ecological change from southwestern Connecticut, USA. Journal of Quaternary Science 24(6): 553-556.

\section{Published Version}

doi:10.1002/jqs.1299

\section{Permanent link}

http://nrs.harvard.edu/urn-3:HUL.InstRepos:4315069

\section{Terms of Use}

This article was downloaded from Harvard University's DASH repository, and is made available under the terms and conditions applicable to Open Access Policy Articles, as set forth at http:// nrs.harvard.edu/urn-3:HUL.InstRepos:dash.current.terms-of-use\#OAP

\section{Share Your Story}

The Harvard community has made this article openly available.

Please share how this access benefits you. Submit a story.

\section{Accessibility}


A record of late-glacial and early-Holocene environmental and ecological change from southwestern Connecticut, USA

W. Wyatt Oswald ${ }^{1,2}$, David R. Foster ${ }^{2}$, Elaine D. Doughty ${ }^{2}$, and Edward K. Faison ${ }^{2,3}$

1 Emerson College, Dept. of Communication Sciences and Disorders, Boston, MA 02116, USA

2 Harvard University, Harvard Forest, Petersham, MA 01366, USA

3 Highstead, Redding, CT 06875, USA

Author for correspondence:

W. Wyatt Oswald

Emerson College

Dept. of Communication Sciences and Disorders

Boston, MA 02116

Phone: 617-824-3502

Email: w_wyatt_oswald@emerson.edu

April 20, 2009; resubmitted to Journal of Quaternary Science as a Rapid Communication 


\section{Abstract}

Analyses of a sediment core from Highstead Swamp in southwestern Connecticut, USA

3 reveal late-glacial and early-Holocene ecological and hydrological changes. Late-glacial pollen

4 assemblages are dominated by Picea and Pinus subg. Pinus, and the onset of the Younger Dryas

5 (YD) cold interval is evidenced by higher abundance of Abies and Alnus viridis subsp. crispa.

6 As climate warmed at the end of the YD, Picea and Abies declined and Pinus strobus became the

7 dominant upland tree species. A shift from lacustrine sediment to organic peat at the YD-

8 Holocene boundary suggests that the lake that existed in the basin during the late-glacial interval

9 developed into a swamp in response to reduced effective moisture. A change in wetland

10 vegetation from Myrica gale to Alnus incana subsp. rugosa and Sphagnum is consistent with this

11 interpretation of environmental changes at the beginning of the Holocene.

13 Introduction

14 Environmental and ecological changes associated with the Younger Dryas (YD) climatic

15 oscillation (12,900-11,600 calibrated ${ }^{14} \mathrm{C}$ years before present; cal yr BP) have been studied at

16 many sites in eastern North America using a variety of approaches (e.g., Peteet et al., 1990;

17 Levesque et al., 1993; Mayle et al., 1993; Cwynar and Levesque, 1995; Shemesh and Peteet,

18 1998; Yu and Eicher, 1998; Lavoie and Richard, 2000; Newby et al., 2000; Cwynar and Spear,

19 2001; Huang et al., 2002; Shuman et al., 2001, 2002; Hou et al., 2007; Lindbladh et al., 2007;

$20 \mathrm{Yu}, 2007)$. Pollen records typically feature an increase in cold-tolerant taxa at the beginning of

21 the YD and a shift to taxa indicative of warmer conditions at the YD-Holocene boundary (e.g.,

22 Shuman et al., 2002). Quantitative reconstructions of temperature for this interval yield

23 generally consistent results, indicating $\sim 5^{\circ} \mathrm{C}$ shifts at the beginning and end of the YD (Shemesh 
1 and Peteet, 1998; Yu et al., 1998; Cwynar and Spear, 2001; Yu, 2007). Late-glacial changes in

2 moisture balance, on the other hand, have received less study. Lake-level reconstructions from

3 southern Québec (Lavoie and Richard, 2000) and southeastern Massachusetts (Newby et al.,

4 2000; Shuman et al., 2001) indicate relatively wet conditions during the YD and drier climate at

5 the beginning of the Holocene, but other records of moisture-balance shifts associated with the

6 YD have not been developed. In this paper we report on a late-glacial sedimentary record from a

7 swamp in southwestern Connecticut, USA. Analyses of pollen and organic content provide

8 additional insights into changes in moisture balance at the end of the YD.

10 Study Area

11 Highstead Swamp $\left(41^{\circ} 19.5^{\prime} \mathrm{N}, 73^{\circ} 23.75^{\prime}\right.$ W) is located at Highstead, a 150 -acre

12 woodland preserve in Redding, Connecticut. This area of southwestern Connecticut falls within

13 the Northeastern Coastal Zone, an ecoregion that extends across southern New England (Griffith

14 et al., 1994).

The swamp is part of a 4-ha seasonally flooded basin; it has an intermittent outlet stream

17 that drains into a 1-ha artificial pond before continuing to the southeast. Soils range from muck

18 to poorly drained and stony (Wolf, 1981). The swamp is bounded to the west by a rugged

19 northeast-to-southwest trending ridge of Ordovician-age schist and granitic gneiss; to the east is

20 a smooth, northwest trending drumlin composed of Wisconsinan glacial till overlying Illinoian

21 till (Rodgers, 1985; Stone et al., 2005). The vegetation of the swamp features Acer rubrum and

22 Betula alleghaniensis in the overstory, Clethra alnifolia, Lindera benzoin, and Ilex verticillata in

23 the understory, and a ground layer of Symplocarpus foetidus, Osmunda cinnamomea, and Carex 
1 species. Dry, upland forest to the west consists of 70-90 year old Quercus rubra, Q. coccinea,

2 and Q. prinus, with dense Kalmia latifolia in the understory. To the east, moist Acer rubrum,

3 Fraxinus americana, and Liriodendron tulipifera forest (45-85 years old) occurs on fine-grained

4 soils. The Quercus forest was continuously forested during the European settlement period but

5 was cut heavily for wood products, while the Acer-Fraxinus forest was open pasture during the

6 settlement period and reverted back to woodland only in the twentieth century.

\section{Methods}

9 We collected a sediment core from Highstead Swamp in June of 2006. We accessed the 10 center of the swamp using an established boardwalk and collected a 256-cm-long core using a 11 modified Livingston piston sediment sampler. Core segments were extruded horizontally in the 12 field, wrapped in plastic and aluminum foil, and subsequently refrigerated.

The analyses presented here were performed on the interval of the core from 256 to 94

$15 \mathrm{~cm}$; the upper interval of the core appeared to be disturbed and therefore was not analyzed.

16 Sediment samples of $1 \mathrm{~cm}^{3}$ were prepared for pollen analysis following standard procedures

17 (Faegri and Iversen, 1989), and tablets containing Lycopodium clavatum spores were added

18 during processing to allow calculation of pollen and spore concentrations (Stockmarr, 1971).

19 Pollen residues were mounted in silicone oil and analyzed at 400x magnification. At least 500

20 pollen grains and spores of upland plant taxa were counted for each sample, and pollen

21 percentages were calculated relative to that sum. Myrica-type pollen, which is very abundant in

22 samples from 134 and $138 \mathrm{~cm}$, was not included in the sum used to calculate percentage values. 
1 Sediment organic content was estimated for $1-\mathrm{cm}^{3}$ samples at selected depths by percent weight

2 loss-on-ignition (LOI) at $550{ }^{\circ} \mathrm{C}$.

4 Chronological control is provided by accelerator mass spectrometry ${ }^{14} \mathrm{C}$ analysis of four 5 woody plant macrofossils sieved from the sediment (Table 1). Dates were converted to 6 calibrated ${ }^{14} \mathrm{C}$ years before present (cal yr BP) with CALIB 5.0 (Stuiver and Reimer, 1993). The

7 date of the uppermost sample $(\sim 11,900 \mathrm{cal} \mathrm{yr} \mathrm{BP} ; 109 \mathrm{~cm})$ is inconsistent with the age-depth 8 relationship of the other dates and data from other sites, and is therefore rejected.

10 Results

11 The lower section of the core $(256-210 \mathrm{~cm} ; \sim 13,300-13,000$ cal yr BP) is lacustrine 12 sediment featuring pollen assemblages dominated by Picea $(\sim 30 \%)$ and Pinus subgenus Pinus $13(\sim 30 \%)$, with minor abundances of Ostrya-Carpinus, Fraxinus, Quercus, Betula, Poaceae, 14 Cyperaceae, and pteridophytes (Fig. 2). Organic content increases from $~ 50$ to $60 \%$ during this 15 interval (Fig. 3). Various changes occur after $\sim 13,000$ cal yr BP (220-200 cm), including 16 increased abundance of Abies, Alnus, Nuphar, and Myrica-type and decreasing percentages for 17 Ostrya-Carpinus, Fraxinus, Quercus, Poaceae, and pteridophyes (Fig. 2-3). Organic content 18 declines abruptly between $\sim 220$ and $200 \mathrm{~cm}$, then increases from $\sim 50$ to $70 \%$ between 200 and

$19140 \mathrm{~cm}$. The upper section of the core $(140-90 \mathrm{~cm} ;<11,500 \mathrm{cal} \mathrm{yr} \mathrm{BP})$ changes abruptly to peaty 20 sediment, with organic content increasing from $\sim 70$ to $90 \%$. This interval has a dramatic decline 21 in Picea pollen percentages $(-30$ to $<5 \%)$ and a corresponding rise in Pinus subgenus Strobus 22 abundance ( $\sim 5$ to $60 \%)$. Abies abundance declines above $140 \mathrm{~cm}$, whereas Tsuga pollen reaches $23 \sim 2-3 \%$ and Alnus pollen peaks at $\sim 40 \%$. Myrica-type pollen becomes very abundant in samples 
1 at the beginning of this transition (Fig. 3), just before the peak in Alnus pollen percentages, while

2 Sphagnum spores reach a peak coincident with the highest Alnus values.

4 Discussion

5 The changes observed in the Highstead Swamp record at $\sim 13,000$ cal yr BP, including 6 declining percentages of Ostrya-Carpinus pollen and higher abundances of Abies and Alnus 7 (presumably A. viridis subsp. crispa), are consistent with pollen data from sites in southern New 8 England (e.g., Davis, 1969; Suter, 1985; Lindbladh et al., 2007) and elsewhere in eastern North 9 America (e.g., Mayle et al., 1993; Peteet et al., 1993). The $\sim 5^{\circ} \mathrm{C}$ drop in temperatures at the 10 beginning of the YD (Shemesh and Peteet, 1998; Yu et al., 1998; Cwynar and Spear, 2001; Yu, 11 2007) appears to have shifted vegetation assemblages across the region towards cold-tolerant

12 taxa (Shuman et al. 2002), although some ecological changes may have been underway in 13 advance of the onset of YD cooling (Lindbladh et al., 2007).

The end of the YD cold interval in the Highstead Swamp record is also marked by changes in vegetation seen at other sites. Picea pollen percentages decline abruptly at $\sim 11,500$

17 cal yr BP, and boreal taxa such as Abies are replaced by temperate taxa including Pinus strobus,

18 Tsuga canadensis, and Quercus (e.g., Mayle et al., 2003; Shuman et al. 2002; Lindbladh et al.,

19 2007). A comparison of pollen and paleoclimatic data by Williams et al. (2002) indicates that

20 vegetation responded quickly to rising temperatures at the beginning of the Holocene. The peak

21 in Alnus pollen percentages at the YD-Holocene boundary in the Highstead Swamp record, 22 however, is not a feature that is normally observed in other pollen records from eastern North 23 America (but see Newby et al., 2002). In fact, the decline of Alnus is typically seen as a 
1 distinguishing marker of the end of the YD (Mayle et al., 1993). We interpret the increase in

2 Alnus abundance, as well as the rise in Myrica-type pollen occurring just prior to the Alnus peak,

3 as evidence for changes in the composition of the local vegetation in response to a shift in

4 moisture availability and hydrological conditions at the beginning of the Holocene.

6 Several lines of evidence from the Highstead Swamp record indicate a sequence of 7 hydrological and ecological changes during the transition from the YD to the Holocene. The 8 decline in the abundance of Nuphar, an aquatic plant, and shift from lacustrine sediment to peat 9 suggest that the lake that occupied the basin during the late-glacial interval became a swamp 10 after $\sim 11,500$ cal yr BP. A similar transition in the sediments of Makepeace Cedar Swamp, 11 located in southeastern Massachusetts, was also interpreted as a shift from lake to swamp at the 12 beginning of the Holocene (Newby et al., 2000). The changes in wetland vegetation at 13 Highstead Swamp are consistent with this interpretation. The wet substrate of the swamp was 14 initially dominated by Myrica gale, as evidenced by the high abundance of Myrica-type pollen, 15 and subsequent development of the swamp likely allowed Alnus and Sphagnum to become 16 prevalent. We suspect that the Alnus pollen represents the presence of Alnus incana subsp. 17 rugosa, which can occur with Sphagnum in bogs and swamps in eastern North America (e.g., 18 Cronan and DesMeules, 1985).

Taken together, the changes observed in the sedimentary record from Highstead Swamp

21 are consistent with lake-level studies from eastern North America (Lavoie and Richard, 2000;

22 Newby et al., 2000; Shuman et al., 2001), which suggest that water levels declined 11,500 cal

23 yr BP in response to declining effective moisture. Those dry conditions prevailed in New 
1 England until $~ 8000$ cal yr BP, when the deterioration of the Laurentide Ice Sheet brought wetter

2 climate to the region (e.g., Shuman et al., 2006).

3

4 Acknowledgements

5 We thank Highstead (www.highstead.net) for their support of this research. Bryan

6 Shuman, Jason Briner, and two anonymous reviewers provided valuable suggestions. Alex

7 Ireland helped in the field and Brian Hall assisted with figures.

8 


\section{References}

3 Cronan CS, DesMeules MR. 1985. A comparison of vegetative cover and tree community 4 structure in three forested Adirondack watersheds. Canadian Journal of Forest Research 15: $5 \quad 881-889$.

7 Cwynar LC, Levesque AJ. 1995. Chironomid evidence for late-glacial climatic reversals in 8 Maine. Quaternary Research 43: 405-413.

10 Cwynar LC, Spear RW. 2001. Lateglacial climate change in the White Mountains of New 11 Hampshire. Quaternary Science Reviews 20: 1265-1274.

13 Davis MB. 1969. Climatic changes in southern Connecticut recorded by pollen deposition at 14 Rogers Lake. Ecology 50: 409-422.

16 Faegri K, Iversen J. 1989. Textbook of Pollen Analysis. Fourth edition. John Wiley and Sons, 17 Chichester, UK.

Griffith GE, Omernik JM, Pierson SM, Kiilsgaard CW. 1994. The Massachusetts Ecological 20 Regions Project. US Environmental Protection Agency, Corvallis, OR, USA.

22 Hou J, Huang YS, Oswald WW, Foster DR, Shuman B. 2007. Centennial-scale compound23 specific hydrogen isotope record of Pleistocene-Holocene climate transition from southern New 24 England. Geophysical Research Letters 34: L19706.

27 lacustrine sediments record late-Quaternary climate variations. Geology 30: 1103-1106.

29 Lavoie M, Richard PJH. 2000. Postglacial water-level changes of a small lake in southern 30 Quebec, Canada. The Holocene 10: 621-634. 
1 Levesque AJ, Mayle FE, Walker IR, Cwynar LC. 1993. A previously unrecognized late-glacial

2 cold event in eastern North America. Nature 361: 623-626.

3

4 Lindbladh M, Oswald WW, Foster DR, Faison EK. 2007. A late-glacial transition from Picea

5 glauca to Picea mariana in southern New England. Quaternary Research 67: 502-508.

7 Mayle FE, Levesque AJ, Cwynar LC. 1993. Alnus as an indicator taxon of the Younger Dryas

8 cooling in eastern North America. Quaternary Science Reviews 12: 295-305.

10 Newby PE, Killoran P, Waldorf MR, Shuman BN, Webb RS, Webb T. 2000. 14,000 years of 11 sediment, vegetation, and water-level changes at the Makepeace Cedar Swamp, southeastern

12 Massachusetts. Quaternary Research 53: 352-368.

14 Peteet DM, Daniels RA, Heusser LE, Vogel JS, Southon JR, Nelson DE. 1993. Late-glacial 15 pollen, macrofossils and fish remains in northeastern U.S.A. - the Younger Dryas oscillation. 16 Quaternary Science Reviews 12: 597-612.

18 Rodgers J. 1985. Bedrock Geological Map of Connecticut. Connecticut Geological and Natural 19 History Survey, Hartford, CT, USA.

21 Shemesh A, Peteet D. 1998. Oxygen isotopes in fresh water biogenic opal - Northeastern US

22 Alleröd-Younger Dryas temperature shift. Geophysical Research Letters 25: 1935-1938.

24 Shuman BN, Bravo J, Kaye J, Lynch JA, Newby P, Webb T. 2001. Late-Quaternary water-level 25 variations and vegetation history at Crooked Pond, southeastern Massachusetts. Quaternary 26 Research 56: 401-410.

28 Shuman B, Webb T, Bartlein P, Williams JW. 2002. The anatomy of a climatic oscillation: 29 vegetation change in eastern North America during the Younger Dryas chronozone. Quaternary 30 Science Reviews 21: 1777-1791. 
1 Shuman B, Huang Y, Newby P, Wang Y. 2006. Compound-specific isotopic analyses track

2 changes in the seasonality of precipitation regimes in the northeastern United States at ca. 8200

3 cal yr BP. Quaternary Science Reviews 25: 2992-3002.

4

5 Stockmarr J. 1971. Tablets with spores used in absolute pollen analysis. Pollen et Spores 13:

$6 \quad 615-621$.

8 Stone JR, Schafer JP, London EH, DiGiacomo-Cohen ML, Lewis RS, Thompson WB. 2005.

9 Quaternary Geologic Map of Connecticut and Long Island Sound Basin. US Geological Survey, 10 US Department of Interior.

12 Stuiver M, Reimer PJ. 1993. Extended ${ }^{14} \mathrm{C}$ database and revised CALIB radiocarbon calibration 13 program. Radiocarbon 35: 215-230.

15 Suter SM. 1985. Late-glacial and Holocene vegetation history in southeastern Massachusetts: a 16 14,000 year pollen record. Current Research in the Pleistocene 2: 87-89.

18 Williams JW, Post DM, Cwynar LC, Lotter AF, Levesque AJ. 2002. Rapid vegetation responses 19 to past climate change. Geology 30: 971-974

21 Wolf BL. 1981. Soil Survey of Fairfield County, CT. US Department of Agriculture, Soil 22 Conservation Service.

24 Yu Z. 2007. Rapid response of forested vegetation to multiple climatic oscillations during the 25 last deglaciation in the northeastern United States. Quaternary Research 67: 297-303.

27 Yu Z, Eicher U. 1998. Abrupt climate oscillations during the last deglaciation in central North 28 America. Science 282: 2235-2238. 
Table 1. Results of ${ }^{14} \mathrm{C}$ dating for Highstead Swamp

\begin{tabular}{llllrrr}
\hline Depth $(\mathrm{cm})$ & Material & Lab number & $\delta^{13} \mathrm{C}$ & ${ }^{14} \mathrm{C}$ age \pm error & Cal range $(2 \sigma)$ & Median cal age \\
\hline $109-110^{*}$ & Wood & OS-59498 & -27.63 & $10,200 \pm 35$ & $11,760-12,050$ & 11,910 \\
$142-143$ & Wood & OS-59484 & -26.90 & $10,000 \pm 50$ & $11,270-11,710$ & 11,480 \\
$209-210$ & Wood & OS-59499 & -28.31 & $11,100 \pm 50$ & $12,910-13,110$ & 13,010 \\
$257-258$ & Wood & OS-59500 & -25.83 & $11,450 \pm 50$ & $13,210-13,410$ & 13,300
\end{tabular}

*Rejected due to age reversal

\section{Figure captions}

Figure 1. Map of the Highstead Swamp and surrounding topography in Redding, Connecticut, USA. Inset map shows location of Rogers Lake (Davis, 1969).

Figure 2. Pollen percentage diagram for selected taxa from the Highstead Swamp sediment record. Note changing scale for $\mathrm{x}$-axes. Horizontal lines are depths of ${ }^{14} \mathrm{C}$ samples; the $2 \sigma$ calibrated ${ }^{14} \mathrm{C}$ age ranges are shown.

Figure 3. Organic content (percent weight loss-on-ignition; \% LOI), sediment characteristics (light gray is lacustrine sediment, dark gray is peat), and pollen and spore concentrations for selected taxa from the Highstead Swamp sediment record. Note changing scale for x-axes. Horizontal lines are depths of ${ }^{14} \mathrm{C}$ samples; the $2 \sigma$ calibrated ${ }^{14} \mathrm{C}$ age ranges are shown. 


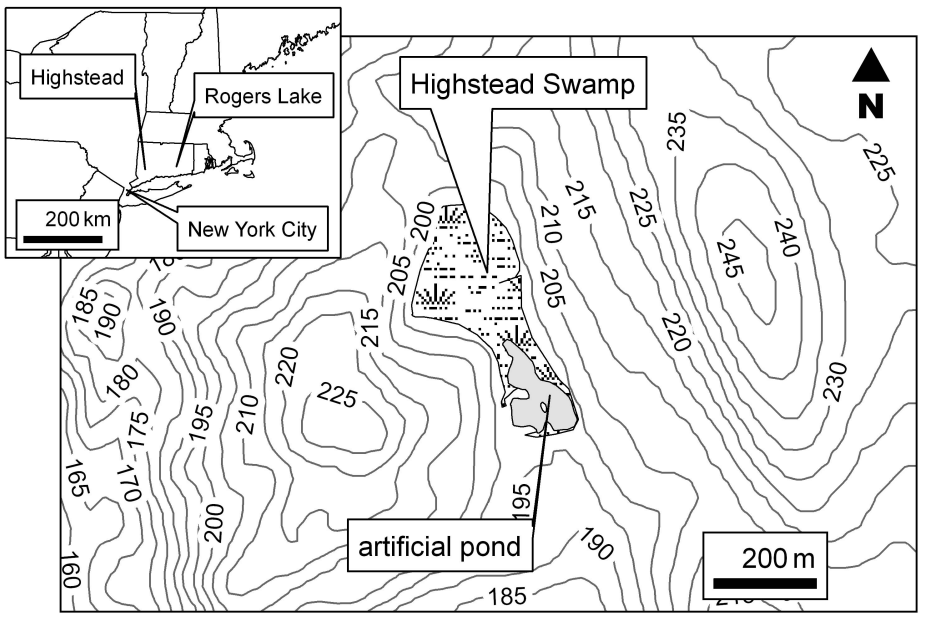




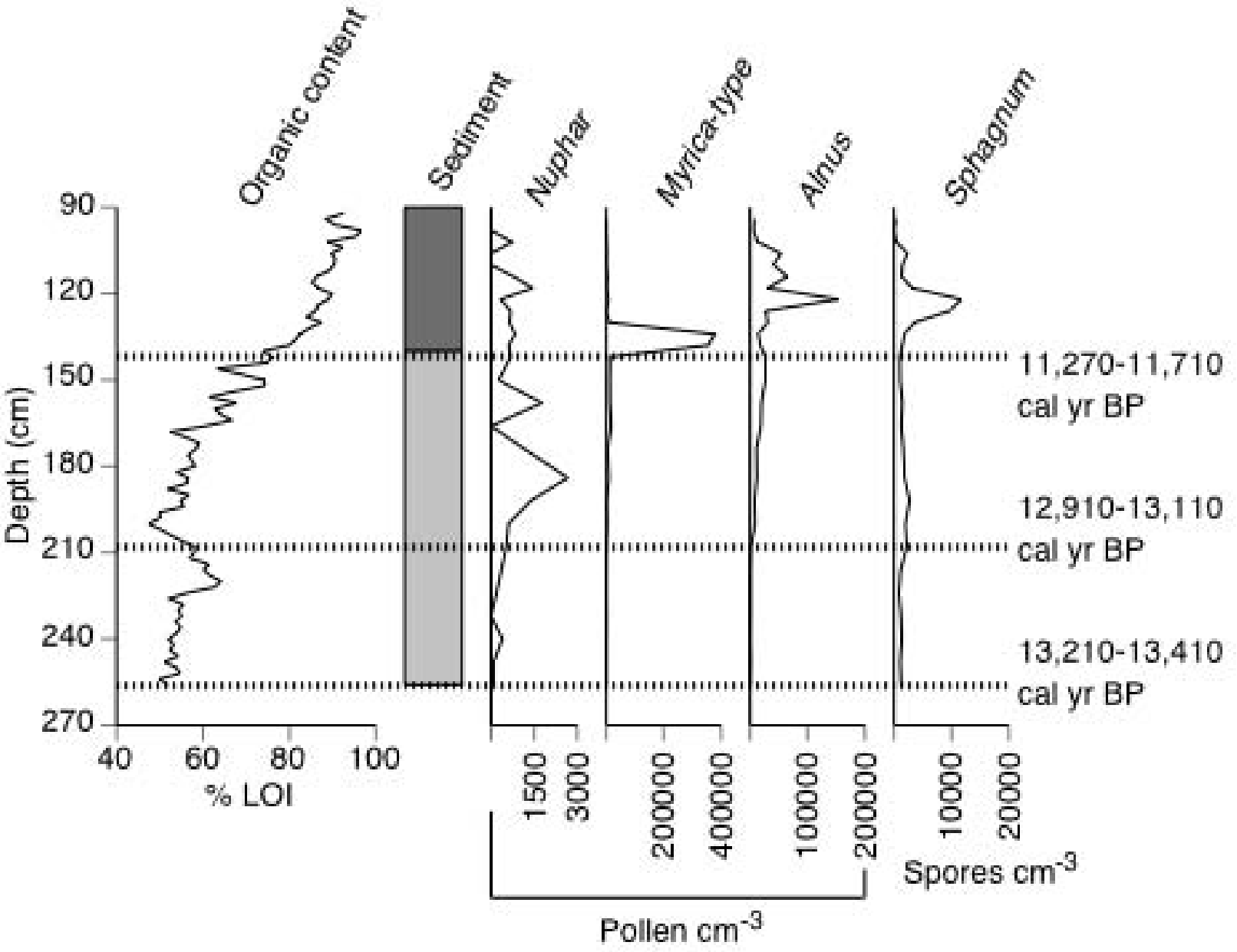

